\title{
The Things of Caesar: Mark-ing the Plural (Mk 12:13-17)
}

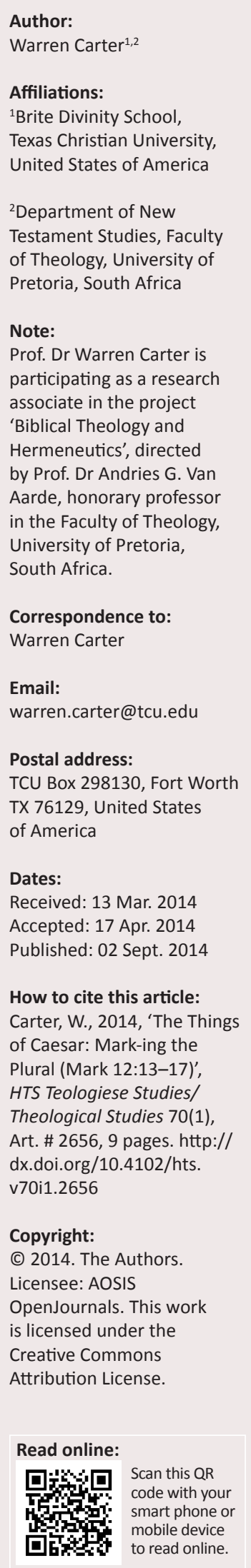

This article observes the rarely-discussed phenomenon that the Marcan paying-the-tax scene refers to tax in the singular, whilst the concluding saying uses the plural 'the things of Caesar and of God'. The article accounts for this phenomenon by means of developing traditions. The section under the heading 'Mark's scene and saying about taxes (12:13-17)' counters the common claim that scene and saying originated as a unit from the historical Jesus. It proposes that whilst the saying may have originated with Jesus, the scene as we have it did not. The section under the heading 'Social memory, orality, and a multi-referential saying?' suggests some contexts that the saying about the things of Caesar addressed pre-Mark. And under the section 'Trauma and Mark's scene' it is argued that Mark created a unit comprising scene and saying to negotiate the 'trauma' of the 66-70 war. The unit evaluates freshlyasserted Roman power as idolatrous and blasphemous whilst simultaneously authorising the continued involvement of Jesus-believers in imperial society.

\section{Introduction}

Despite extensive discussion of the Synoptic paying-the-tax scene (Mk 12:13-17), little attention has been paid to the incongruity between linguistic items in the singular - tax ( $\left.\kappa \tilde{\eta} \sigma \mathrm{ov},{ }^{1} \mathrm{Mk} 12: 14\right)$,

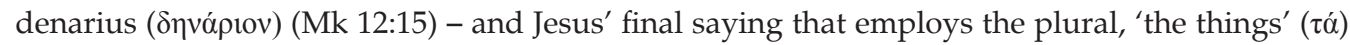

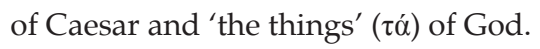

How might we account for this disjuncture? In this article, I propose doing so in terms of the diachronic development of the scene and saying.

Though we cannot know for sure, I argue that the disjuncture arose when Mark attached a multivalent and permissive pre-70 saying to a scene newly created to negotiate the fresh assertion of Roman power in the 66-70 war and its triumphal celebrations (cf. Evans 2006; Incigneri 2003; Winn 2008 for attempts to link Mark with Roman Imperial Power). The argument proceeds in 3 steps. (1) Under the heading 'Mark's scene and saying about taxes (12:13-17)', using redactional, historical and numismatic approaches, I argue that the saying about 'the things of Caesar and of God' is pre-Marcan, whilst the scene involving tax payment is a (largely?) Marcan creation. (2) Under the heading 'Social memory, orality, and a multi-referential saying?', using theories of orality and social memory, I argue that, pre-70, the saying sanctioned the involvements of Jesusbelievers in various imperial structures such as taxes, commerce, imperial cult, and military service. (3) Under the heading 'Trauma and Mark's Scene', using trauma theory, historical, and narrative approaches, I argue that Mark contextualised the saying in a newly created conflictual scene that presented Roman power as blasphemous and idolatrous. The scene reoriented the saying, diminished its previously dominant accomodationist and permissive functions, and heightened the antithesis between Caesar and God, whilst continuing to permit participation in various spheres of Roman power. Basic to this reading is the recognition that Jesus-followers negotiated Roman imperial power in diverse ways.

\section{Mark's scene and saying about taxes (12:13-17)}

Most interpreters argue or assume that Mark's scene originates from Jesus and refers to the annual poll tax, or tax per person, levied after Quirinius' census of 6 CE. The argument is made on source, historical, and numismatic grounds. Rudolf Bultmann observed (1963) that:

It is hardly possible that the saying of Jesus in v. 17 ever circulated independently ... Only in v. 13 can we discern any of Mark's editorial work. There is no reason for supposing that this is a community product. (p. 26; cf. Bruce 1984:250)

1.Horsley (1983:70-71) locates the earliest attested use of this term in the 1st century BCE, in the Black sea region, referring to a Roman census. 
Without discussing the rest of the scene or noticing the disparity of singular and plural terms, Bultmann posits the unity of scene and concluding saying, and argues that the unified unit originates with the historical Jesus.

Historical and numismatic arguments elaborate this claim of a setting in Jesus' ministry in Judea under Roman occupation. The question: 'Is it lawful to pay the tax to the emperor or not?' introduces the tax. Mark identifies the specific coin

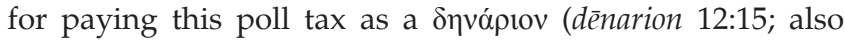
Mt 22:19; Lk 20:24), commonly declared to be 'the money of the tribute', a coin 'in which the tribute ... is to be paid.' This claim was based partly on Matthew's identification of 'the money for the tax' with 'the denarius' (Mt 22:19), and partly on an inscription from Palmyra dating to 136-137 CE (Bruce 1984:258; Davies \& Allison 1988-1997:216; Hart 1984) (OGIS 629, lines 153-156). The denarius in Mark 12 is identified as one likely minted at Lugdunum in Gaul during Tiberius' reign (14-37 CE). The obverse displayed a head of Tiberius laureate with the legend, TI CAESAR DIVI AVG F AVGVSTVS [Tiberius Caesar Son of the Divine Augustus]. The reverse featured the abbreviation PONTIF MAXIM (Pontifex Maximus) with a seated woman, probably pax [peace] personified, perhaps as the emperor's wife, Livia. ${ }^{2}$

But is this conventional analysis convincing? Three factors suggest that the scene does not originate in the ministry of the historical Jesus and does not refer to a poll tax.

The first factor concerns Bultmann's confidence in the unity of scene and saying, and their origin in Jesus' ministry. Several features suggest that the concluding saying of verse 17 is pre-Marcan. Its dominant stylistic feature, the

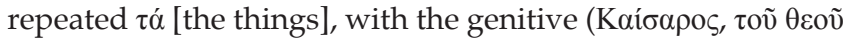
[of Caesar, of God]), is not typical of any of the synoptics. ${ }^{3}$ Its 'patterned and predictable form', featuring contrasting items, reflects oral speech that held disparate elements together (Kelber 1983:27). Its content is theocentric, not

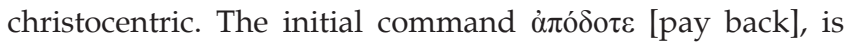
Mark's only occurrence of $\dot{\alpha} \pi$ o $\delta i \delta \omega \mu$ [I pay back] as is the concluding verb $\dot{\varepsilon} \xi \varepsilon \theta \alpha v \mu \alpha ́ \zeta o v$ ([wonder greatly]; Mk12:17). These features of vocabulary, style, and content suggest a pre-Marcan saying.

The rest of the scene, however, is by no means clearly preMarcan. Some non-Marcan features appear: the only Marcan

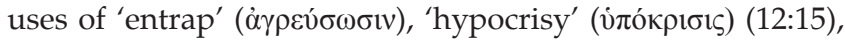

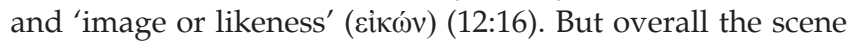
appears very Marcan. The historic present tense dominates.

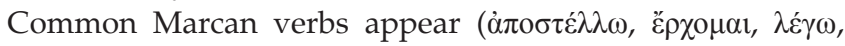
$\beta \lambda \varepsilon \dot{\pi} \omega, \check{\varepsilon} \xi \varepsilon \sigma \tau \imath v$ [I send, I come, I say, I see, it is necessary]), as does the vocative $\delta 1 \delta \alpha ́ \sigma \kappa \alpha \lambda \varepsilon$ [teacher], (10 times in Mk; 6 in Mt). Mark uses the impersonal construction ov̉ $\mu \varepsilon \dot{\lambda} \varepsilon \varepsilon$ бoı

2.Pilgrim (1999:66-72) identifies four interpretations for the historical Jesus' teaching (1) two legitimate kingdoms equally meriting obedience; (2) obedience to God only since nothing belongs to Caesar; (3) two legitimate realms with God's claims taking political realm.

3.Mark uses $\tau$ ó 51 times; four times followed by a genitive, two of which occur in Mark $12: 17$, and in Mark 8:33. Matthew adds two references, making six uses of $\tau \dot{\alpha}$ with a genitive in 109 appearances (Mt 8:33; 16:23 [2 x]; 24:17). In Luke's 104 uses of $\tau \dot{\alpha}$, it appears with a genitive only in Luke 20:25 (Giblin 1971:520-525).
(Mk 12:14; 'it is not a concern or care') twice (cf. Mk 4:38; 7 times in the New Testament [NT]), both times negated.

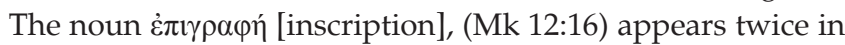
Mark (cf. 15:26; $5 \mathrm{x}$ in the NT). The unhistorical pairing of 'the Herodians and the Pharisees' occurs only here and Mark 3:6 in the Synoptics (Meier 2001:560-565). The presence of Herodians in Jerusalem is unlikely given that (during Jesus' ministry) Herod Antipas was tetrarch of Galilee.

It seems reasonable to conclude, then, that whilst the saying in verse 17 is probably pre-Marcan, numerous Marcan features in the rest of the scene suggest its Marcan construction. Bultmann's confidence in the unity of scene and saying, and in the unit's pre-Gospel origin, appears misplaced.

Secondly, historical factors question the scene's origin with the historical Jesus. Fabian Udoh (2005:207-238) argues there was no poll tax in Judea prior to 70 CE. After the war, the emperor Vespasian co-opted the temple tax and levied it on the defeated Jews for the temple of Jupiter Capitolinus in Rome. Discussing Josephus's two references to Quirinius's census in 6 CE, Udoh (2005:214-218) argues that the census registered only property for taxation and not persons for a poll tax (Josephus Ant. 18.3, JW 7.253). Judas the Galilean, he argues, opposed payment of property tax (tributum soli), not a poll tax, rebuking those who paid this tribute ( $\tau \varepsilon \lambda \varepsilon \tilde{v} v$ ) and inciting revolt (Josephus JW 2.118; cf. Ant. 18. 273-18.275). ${ }^{4}$ Udoh (2005:223) argues that there is no evidence for a tributum capitis [poll tax or tax per person] 'before $70 \mathrm{CE}^{\prime}$. And, in Udoh's view (2005:223-238), Mark 12:13-17 provides no such evidence: the alliance of Pharisees and Herodians is

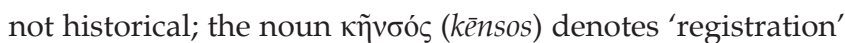
not a particular form of (poll) 'tax'; Jesus' call for a 'denarius' and Matthew's equation of the 'denarius' with 'the money for the tax' are not reliable historical data because taxes were not levied in coins or precisely in denarii; they were more commonly (though not exclusively) paid in kind; the Palmyra inscription addresses city tolls not Roman taxes or tribute; and denarii were common in Jerusalem only post-70 whilst pre-70, Tyrian silver coins or shekels dominated.

If Udoh is right, he has demolished the consensus view that the scene and saying originated together with the historical Jesus. Evaluating his argument, though, is challenging. Matters pertaining to taxation in the Roman Empire are difficult to decide because evidence is lacking. What evidence does exist - particularly from Egypt - indicates there was not a standard system across the Empire and that through the 1st century, practices developed in different ways and regions. ${ }^{5}$ Can the limited data be generalised to Judea?

One crucial aspect of Udoh's argument is the claim that assessment of property by Quirinius's census for tribute payment in $6 \mathrm{CE}$ does not simultaneously involve counting persons for a poll tax. Determining whether Udoh is right in

4.In Josephus, (JW 2.433), Judas the Galilean "upbraid(s) the Jews for recognizing the Romans as masters when they already had God.

5.Wallace ([1938] 1969:116-134) argues that the poll tax was universal in Egypt, introduced by Augustus with the census of 24-23 BCE. 
separating the two in contrast with the widespread scholarly equation of census with poll tax, however, is difficult. Josephus' descriptions of the census of 6 CE, to which Udoh appeals, does not clarify this issue. The Loeb translator, Louis Feldman, translates Josephus's description of Quirinius's task only in relation to property, but without clarifying the relationship between registration of property and of

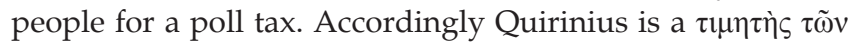

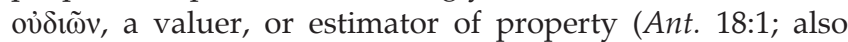

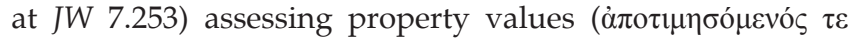

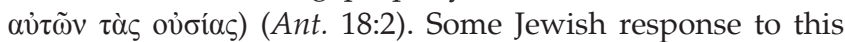

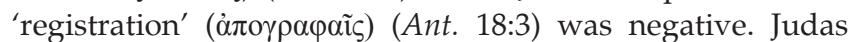
along with Saddok the Pharisee viewed 'the assessment' ( $\left.\tau \eta^{\prime} \tau \varepsilon \dot{\alpha} \pi \circ \tau i ́ \mu \eta \sigma \iota\right)$ as slavery, and incited rebellion, whilst the chief priest Joazar ensured some 'declar[ed] the value of their

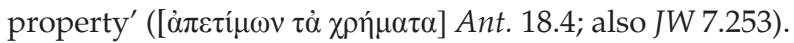

Is only property tax in view as Udoh claims, or does property registration also involve registration of persons? The vocabulary is not especially helpful since it appears almost exclusively in references to Quirinius' census: the

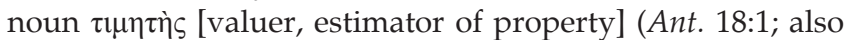

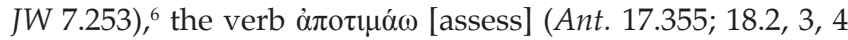
[noun], 26 [noun]), ${ }^{7}$ and the noun $\dot{\alpha} \pi \circ \gamma \rho \alpha \varphi \eta ́$ [assessment] and its cognate verb (except Ant. 12.31). Based on Josephus, one might conclude with Josephus's translator Louis Feldman and Udoh that this language refers only to the registration of property.

But is this conclusion justified by a larger linguistic sample?

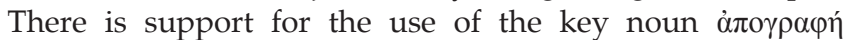
[assessment] and its cognate verb to denote registration of property. In Egyptian documents, these terms refer to registering buildings (Horsley 1981) and animals (P.Oxy. II.246; Deissmann 1922:172-174), the latter perhaps for taxation (for an annual registration in Egypt of 'livestock in private ownership on which we paid a tax per animal' Llewelyn 1997b:81). Yet the language is not a 'technical term' referencing only registration of property for tax purposes. It can also denote registration of peoples such as Jewish persons enrolled or registered for slavery (3 Macc 2:29, 32) and death (3 Macc 4:14, 15, 17; 6:34, 38). ${ }^{8}$ It denotes slaves to be released (Letter of Aristeas 20, 24; Josephus Ant. 12:31), persons 'enrolled' or registered for heaven (Heb 12:23), and people enrolled in a census (Lk 2:1-5). ${ }^{9}$ It can indicate birth (P.Oxy 28; Milligan 1927: 81-82), sins and injustices (1 En 98:7), and sins and righteous deeds (Test. Abr. A 13:1, 9; cf. B 11:4).

The term, then, is not a technical term for tax property registration. It also refers to registering people for various

6.Polybius (6.13.3) denotes censors that the senate authorised 'for the repair and construction of public buildings'; Philo (De Spec. Leg 2.37) maintains its economic focus with a priest assessing a house.

7.The exception in Josephus's Ant. 5.76 refers to Joshua sending surveyors to measure

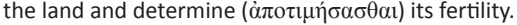

8.The reference in 7:22 refers to Jews recovering 'all their possessions, according to the register', though confiscation of property was not mentioned previously.

9.Barnett (1973-1974:377-380) suggests the term designates in Luke 2:1-5 an 'enrollment' for swearing an oath of imperial allegiance; so Herod to Augustus (Josephus Ant. 17.42) and Vitellius to Gaius Caligula (Ant. 18.124). Barnett fails to note, though, that Josephus does not use this language for such events. purposes. Does it denote the registration of people for taxation when no explicit mention of a poll tax is made?

Several texts suggest that such a link is possible. In P.Oxy 255, dating from $48 \mathrm{CE}$, Thermoutharion and her male guardian Apollonius declare three people in 'the house that belongs to me in the South Lane'. During Hadrian's reign in $133 \mathrm{CE}$, Stephanos aged 17 years registers 'for the house

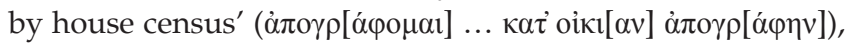
identifying where he dwells ('in a house belonging to Tnephersois and ... in the quarter of the Thoeris Road') but not listing his property nor making any reference to taxation.

What is the purpose of such registration? Milligan (1927:45) argues that 'such returns ... furnished a basis for ... the

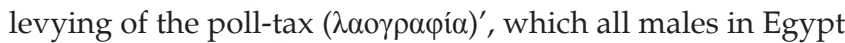
from age 14 to 60 paid. And Llewelyn (1992b:122) claims that at least since 33-34 CE a census for registration was held in Egypt every 14 years. Yet whilst such conclusions linking registration, census, and poll tax seem reasonable, it must be noted that the documents do not explicitly specify that a poll tax was the purpose or consequence of registration.

Perhaps more helpful in clarifying the relationship of census registration and poll tax are the Egyptian documents that express an administrative concern for those who have registered but who have fled a region without tax payment. One document from the prefect Baienus Blastianus offers 'those without means who have fled' a suspension or postponement of capitation taxes (Llewelyn 1992b:112, 11. 1-6). Other documents publish the names of those who have fled their domicile without paying tax (Llewelyn 1997b). These records seem to be the strongest link between registration of people and a poll tax.

But are these data from Egypt relevant to 1st century JudeaGalilee? Does the silence of the historical record indicate no poll tax in Judea, or does it suggest that it was so normal and obvious that it is not mentioned? Udoh takes the former position. Others take the latter view. Classicist Peter Brunt (1990) notes the likelihood of regular census taking throughout the empire and comments:

Regularity, as in Egypt, was surely necessary for the exaction of a capitation tax; in Syria we should expect registration to have taken place at least every twelve years ... And the evidence for tributum capitis is so chancy and so scattered that it is hard to believe that it was not universal, though not of course uniform in incidence. (p. 332)

And Fergus Millar (1993:46, 110) likewise posits a general imperial procedure of the imposition of the census and the raising of tribute' which included 'both a land tax (tributum soli) and a "head-tax".' Where Udoh sees no poll tax, Brunt and Millar see an obvious, general practice.

One could add to this appeal to 'obviousness' the consideration that the Roman Empire was a 'proprietary' state in which control over land, people, and production 
was exerted by 'the collection of taxes, tribute money, rents, and services' for the benefit of the ruling elite (Lenski 1984:214-217). Kautsky (1982:150) declares that 'to rule in aristocratic empires is, above all, to tax.' This proprietary approach is well attested: Juvenal remarks that 'every rare and beautiful thing in the wide ocean ... belongs to the Imperial treasury' (Sat 4.51-4.55). Josephus has king Agrippa construct the Gauls as a people who 'are yet content to be treated as a source of revenue to the Romans' (JW 2.372). Tacitus has Nero's advisers counter Nero's suggestion to abolish indirect taxation by reminding him that 'the dissolution of the empire was certain if the revenues on which the state subsisted were to be curtailed' (Ann 13.50). Tacitus has the general Cerialis remind the suppressed Treviri and Longones of the cost of empire: 'you cannot secure tranquility among the nations without armies, nor maintain armies without pay, nor provide pay without taxes' (Hist 4.73-4.74). Brent Shaw $(1988: 810,820)$ observes that there were 'hundreds of different taxes' in Egypt and he quotes Suetonius's comment that 'there was no object or person on which some sort of tribute was not imposed' (Gaius 40). Taxes on persons and on their property seem a consistent implementation of this 'proprietary view of the state'.

But in the final analysis, whilst such data suggest a poll tax in Judea, they do not establish its certain existence.

If the existence of the poll tax cannot decide the likely origin of the Marcan scene involving the coin, a third dimension casts considerable doubts on the scene's origin in the activity of the historical Jesus. Udoh (2005:228-236) argues that the prominent role of the denarius in the Marcan scene cannot be authentic to the historical Jesus. The numismatic evidence indicates few denarii in Judea pre-70, making it impossible to sustain a scenario in which Judeans used it to pay an annual poll tax. Donald Ariel (1982) argues from his study of the locations of finds of denarii that it is only after $69 \mathrm{CE}$ that they appear in significant numbers in Jerusalem and that before this date Tyrian silver coins overwhelmingly dominate. If a poll tax was levied and if it was paid in coin, it would have been collected in Tyrian silver coins, not Roman denarii. ${ }^{10}$ The Tyrian silver shekel and half shekel, lacking 'any royal or imperial image on the obverse' but employing local images such as ships, the god Melqart ('Lord of the City'), a Tyche-like goddess, a Phoenician temple, and the date palm, were minted from 126-125 BCE until 65-66 CE (Hanson 1980:24, 57-63). That is, whilst Tyrian coins contained images, they did not depict the Roman emperor as Mark's scene requires. Without the denarius and without an image of the emperor, claims that Mark's scene originate with the historical Jesus collapse.

This discussion has raised significant questions about locating Mark 12:13-17 in the activity of Jesus. Two likely conclusions emerge, that the saying about 'giving to Caesar' seems to be pre-Marcan, whilst the scene to which it is attached in Mark's Gospel featuring the denarius is likely to be a Marcan creation. These conclusions cannot of course be certain given the limited data. Yet previous scholarship has not taken these difficulties seriously, nor explored alternative scenarios concerning the origin and function of the material.

\section{Social memory, orality, and a multi-referential saying?}

Given these conclusions, two questions require attention. How did the saying with its plural referents 'travel' amongst Jesus-believers in the imperial world of the 30s-60s? And in what circumstances might Mark's scene that contextualises the saying in relation to the post-70 poll tax have come into being?

Discussions of the transmission of Jesus traditions in an oral context and studies of social memory highlight several important dimensions of a likely transmission process (standard works include Fentress \& Wickham 1992; Halbwachs 1992; in NT studies Horsley 2008:109-168; Horsley, Draper \& Foley 2006; Kirk \& Thatcher 2005). One dimension concerns social context. Material survives only when it remains relevant to the ongoing life of a group (Aguilar 2005:60), what Werner Kelber (1983:24) calls 'the law of social identification.' Kelber (1983) comments:

What lives on in memory is what is necessary for present life ... Spoken words ... always transpire in social contexts ... survival and continuity of spoken words ... was intimately connected with their social relevancy and acceptability. (p. 24)

Words that found 'an echo in people's hearts and minds' survived (Kelber 1983:15, 23-24). The 'render-to- Caesar and to God' saying survived in the 30 s - 60s because it found resonance with the daily societal experiences of groups of Jesus-believers, engaging changing social locations and the ongoing need for social identity, boundaries and guidance concerning practices.

Fluidity identifies a second dimension of transmission. Kelber (1983:27-34) observes that 'spoken words enter into a social contract, thrive on communal response, and, if they are to be successful, share in and play on collective interests.' Oral transmission is a transforming process. It 'can show infinite flexibility in molding a message so as to make it compatible with social needs ... in orality tradition is almost always composition in transmission' (Kelber 1983:27, 34). Transmission, then, is not devoid of interpretation or creativity or community or contemporary appeal, or contest.

This latter element seems to have been important for the things-of-Caesar-and-things-of-God saying. Interpreters have struggled to understand the relation of the two clauses concerning Caesar and God that the conjunctive $\kappa \alpha i$ [and] holds together. Given the fluidity of transmission, we might posit that this two-part construction reflects and emerged from debate over the contested issue of how Jesus-believers engage their society. The saying suggests a compromise that 
legitimated imperial involvement by placing Caesar in the initial clause, whilst relativising it - but not replacing it with the reference to God.

A third dimension of transmission notes that in contrast to older form-critical models, it is most unlikely that the saying about rendering to Caesar and to God was transmitted as an isolated entity. Rather it more likely 'travelled' as part of a larger unit of sayings or as part of a narrative scene or scenes that addressed significant and communal needs requiring the attention and negotiation of Jesus-followers (Fentress \& Wickham 1992:73). Horsley (2008:14-16, 109-168) develops this point with attention to Israelite traditions. Horsley, though, emphasises (2008:136-137, 164-168) the disruptive, antagonistic, oppositional function of social memory, neglecting its conserving, socially cohesive and accommodating dimensions. Part of the saying's durative value was its flexibility to address a plurality of contexts and issues. Such transmission means that 'memories are contextually recreated within a setting that cannot be the original one' but which address different and emerging questions (Aguilar 2005:65). Performance is composition.

Identifying the originating context is impossible given the destabilising reorientation of this transmission process. James Dunn's (2003:247) and Richard Horsley's (2008:138) suggestions about the transmission of Mark 12:13-17 fail because they assume Bultmann's unconvincing argument that both saying and scene originated with the historical Jesus. Dunn suggests that Mark 12:13-17 was transmitted as part of a unit comprising Mark 12:13-37 concerned with conflict in Jerusalem. Horsley argues that 'giving tribute to Caesar [is] rooted in the Mosaic covenant' and is likely to have been transmitted with similar covenant-based material. Given social relevance, fluidity and flexible address, what issues might this saying have engaged in the 30s -60 s as part of instructional material?

Numerous 'things of Caesar' constituted the world of Jesusfollowers. One such structure involved paying tribute (at least on property) and indirect taxation comprising 'tolls and duties' on goods (Udoh 2005:238-41). These latter taxes assume involvement in economic activity embedded in imperial structures, whether associations (Harland 2003), commerce (Kraybill 1996), or trade (Bauckham 1993). Hanson and Oakman (1998:106-110) suggest possible taxes paid to Herod Antipas and as tribute to the emperor associated with the Galilean fishing economy: leases for fishermen; licenses for processors and taxes on supplies of salt, wine, and oil; road and port usage taxes on distributors; and license and sales taxes on buyers and sellers. Coins minted in Jerusalem by governor Valerius Gratus (15-26 CE) featured images of the caduceus (representing the god of trade, Mercury) and cornucopia to depict abundance (Taylor 2006:558). That is, if we give primacy of the first clause of the instruction to 'render to Caesar' and recognise the connective rather than disjunctive function of kai, the saying functioned permissively to guide Jesus-believers in negotiating Rome's pervasive taxing power by permitting involvement in trade and commerce. It constituted the group's practice as primarily accommodationist and its boundaries as porous in relation to socio-economic participation, albeit whilst expressing loyalty to God who did not impede societal and imperial activity.

Beyond taxes and commerce, imperial cult observance comprised another of 'the things of Caesar' requiring negotiation. In relation to Judea-Palestine, Monika Bernett points to Herod's establishment of imperial cult temples in Sebaste, Caesarea Maritima, and Paneion or Banias (cf. Josephus Ant. 15.267-88, including opposition), Antipas' founding of Tiberias in Galilee, Gaius Caligula's efforts to install a statue of himself as Zeus in the Jerusalem temple, and Agrippa I and II's selective support in Caesarea Maritima and beyond (Bernett 2007a, 2007b; McLaren 2005). Numismatic evidence suggests increasingly vigorous promotion of the cult in the 40s - 60s (Bernett 2007b:352-353).

Joan Taylor (2006:556-563) argues that Governor Pilate promoted the imperial cult through iconography on bronze coins minted in Jerusalem 29-31 CE. His use of the lituus (symbolising an augur's authority) and the simpulum (a priestly ladle-like utensil used for sampling the wine of libations poured on a sacrificial animal's head) reflected Roman religious practice and specifically the emperor Tiberius' roles and identity as a priest and augur, evoking the imperial cult temples of Sebaste and Caesarea Maritima. The Pilate inscription from Caesarea Maritima, though somewhat elusive in attempts at restoration, suggests Pilate dedicated a Tiberieum to the Augustan gods at Caesarea Maritima expanding the existing cult and encouraging honouring of Tiberius (Taylor 2006:564-575). Literary evidence (Philo Leg. ad Gaium 299-305) confirms Pilate executing his duty as Roman governor to encourage imperial honouring (Bilde 1978; Carter 2008:343-384; Taylor 2006:575-582). Whilst these examples have focused on Judea-Galilee, the imperial cult was of course observed across the empire; the pre-Marcan usefulness of the saying was not restricted to Judea-Palestine.

How did the 'render to Caesar' saying engage imperial cult practices? A long tradition of NT scholarship claims Christian refusal to offer sacrifices to idols including worship of imperial images was obvious (Aland 1968:134). This claim, however, is not supportable. If it was widely known that offering sacrifices to idols was forbidden, instructions against sacrifices such as 1 Corinthians 8-10, Acts 15:20, Revelation 2:6, 14-16, 20-23 (Ephesus, Pergamum, Thyatira; Carter 2009) and Revelation 13 against emperor worship would not be needed. Nor would the command of 1 Peter 2:17 to honour the emperor make sense of the letter's strategy of gaining a good name by societal good works if imperial worship was exempt - since there is no exceptive clause (Carter 2004). First Peter 4:3 warns against excessive or 'wanton idolatry'. We cannot assume that it was obvious to all Jesus-believers that avoiding imperial cult activity - almost impossible to do in civic and association activities - was the norm. In relation to the imperial cult, the saying was permissive in guiding 
practice, creating porous boundaries and securing identity for Jesus-followers, whilst upholding loyalty to a God who did not impede such civic-cultic involvement.

Another possible referent for the saying involves Jesusbelievers joining military forces, whether resistance forces in the 66-70 CE war or imperial auxiliary troops ${ }^{11}$ such as those Vespasian assembled with Roman legions in Syrian Antioch in 66-67 before marching south against Jerusalem (Josephus $J W 3.8,29)$. The presence of Jesus-followers in the army is usually framed as a post 2nd-century issue with the earliest evidence from Tertullian (Apology 5.6), Clement of Alexandria (Protrepticus 10.100), and Origen (Contra Celsum 8.73-75; Claus 2001:431-448; Helgeland 1979:735-744; Hegeland, Daly \& Burns 1985; Swift 1979:846-856; 1983). But there is no reason to think that 1st century Jesus-followers abstained from the army (Bainton 1960:67-68). As noted above, opportunities existed in the 1st century, as did incentives of citizenship, salary, pension, and land (Helgeland 1979:797). Luke 3:14 has John the Baptist instruct soldiers without calling them to leave the army, nor is Cornelius, 'a centurion of the Italian cohort', required to abandon the army when he is baptised with the Spirit and water (Ac 10:1, 30-48). And the later opinions of those opposing involvement (Tertullian, Origen) cannot be assumed to represent a general consensus. Tertullian's strong denunciation in De Corona 1, 6 suggests some Jesusbelievers did not find the sacramentum [oath], military crown, or honouring of camp standards an impediment to military participation (Helgeland 1978). For such believers, the saying about rendering to Caesar permissively legitimated military involvement whilst exhorting loyalty to a God who did not impede military participation. ${ }^{12}$

I have noted several possible arenas in which Jesus-believers (30-60 CE) negotiated Roman structures: taxes; commerce, the imperial cult and military service. I have suggested that in these contexts the commands to 'render to Caesar and to God' permit participation even whilst recognising loyalty to God who sanctions involvement.

\section{Trauma and Mark's scene}

In what context did Mark's scene in 12:13-17 emerge in which the denarius with its imperial image and inscription play a central role, and to which the saying about the 'the things of Caesar' is attached? ${ }^{13}$

Basic to my argument is recognising a new context and time. Separating the pre-Marcan and Marcan worlds is the 66-70

11. Helgeland (1979:795-96) notes that membership of legions was restricted to freeborn Roman citizens until 212 when Caracalla granted citizenship to everyone in the empire. Pliny (Epistles 10.29-30) describes two slaves who by concealing their status nearly took the oath - with dire consequences for them and the recruiting officer. Auxiliary forces attracted provincials with incentives of job, food, pension, citizenship and land upon discharge.

12.For those joining rebel forces, the saying might be ambiguous. Does 'rendering to Caesar' mean submission thereby forbidding military opposition? Or does it permit participation in war by imitating militaristic Caesars, even in military action against Rome?

13.Rist (1936:325-328) mistakenly emphasises ethnicity whereby Mark reshapes a scene addressed to Jewish Christians concerning taxation into a scene forbidding Gentile Christians worshipping the emperor.
CE war. My argument is that the fall of Jerusalem and Roman and Flavian celebrations were experienced as 'traumatic' by some Jesus-believers and that Mark's literary scene and saying emerged from, reflected, and addressed that trauma. The perceptual term 'traumatic' requires consideration.

In his discussion of 'collective trauma', Jeffrey Alexander (2004:8) emphasises that trauma is a lived or experienced categorisation, a 'socially mediated attribution.' An event is traumatic when some in a group constitute or represent it to be traumatic. This representation happens when some experience abrupt change, or when something shatters a 'sense of well-being', or causes social pain that is experienced as endangering or threatening a group's identity: 'who they are, where they come from, where they want to go' (Alexander 2004:2-3, 10). That is, an event activates amongst some ('carrier groups'; Alexander 2004:11) 'cognition and rational understanding'. Meaning-making occurs through a process that involves naming and defining the pain, establishing the victims, delineating relevance for a wider group, and attributing responsibility for the event. As a result, a new story emerges that revises and reconstructs the collective identity producing a new normativity and routinisation (Alexander 2004:5, 12-15, 23-24). This reconstruction can function to embrace the sufferings of others and 'expand the circle of the we' (Alexander 2004:1) thereby securing societal connection and solidarity, or it can exclude others and refuse societal recognition and connection.

Following Alexander, I am suggesting that some Jesusbelievers experienced events surrounding the Jewish War and Flavian victory-triumphal celebrations in Rome as 'traumatic'. The trauma arose not necessarily from a physical or social attack, but because this fresh and overwhelming assertion of Roman power posed unsettling questions and doubts about God's purposes and power, Israel's destiny, and their own place in the Roman world as followers of one who had been crucified by Rome. Mark's scene involving a denarius, perhaps one depicting Nero as Johnson (n.d.) suggests, emerges from a meaning-making process (akin to that sketched by Alexander?) activated by this experience interpreted as trauma.

Mark's story of Jesus' conflict with the temple leaders in Jerusalem (in which context this coin scene is located) and of Jesus' crucifixion by an alliance comprising Roman governor and Jerusalem leadership addressed this crisis of identity. Given that stories not only represent events but also connect, clarify, and interpret them (Fentress \& Wickham 1992:51), this coin scene and its final saying contribute an interpretation of the traumatic events and victory of 66-70, forging an identity and way ahead for Jesus-believers. I argue that the pervasive conflict in scene and saying recognises a new situation marked by a heightened sense of the empire's overwhelming power. Mark's use of the coin provides a somewhat coded analysis of this fresh assertion of Roman power as idolatrous and blasphemous. The ambivalent final saying confirms this antithesis of God and Caesar whilst at 
the same time legitimating and sanctioning the participation of Jesus-believers in Caesar's world. How does this happen?

Mark constructs a scene that highlights conflict and hostility, drawing the lines sharply between Jesus and his adversaries; the Rome-allied retainers (cf. Carter 2006 on the structure of the Roman Empire). The tax coin exhibits the scene's central concern not just with tax but with Roman claims and structures of sovereignty that the tax represents:

- Those who want to arrest Jesus (Mk 12:12) 'send' agents, Pharisees and Herodians, to 'entrap him' (Mk 12:13). When the Pharisees and Herodians previously appeared together, they sought to 'destroy' Jesus (Mk 3:1-6). This oppositional framing of Jesus against agents of the Romeallied temple authorities anticipates the final saying of the scene which aligns the temple with 'the things of Caesar', not with 'the things of God'.

- After an ambivalent comment about Jesus being 'true' and teaching 'the way of God' - flattery at best, mockery at worst (Mk 12:14) - they ask a 'yes or no' question

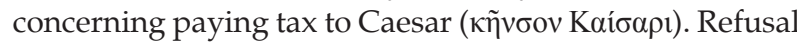
to pay tax signified rebellion as Josephus's King Agrippa declares to the Jerusalemites in 66 CE:

But your actions are already acts of war against Rome: you have not paid your tribute to Caesar... If you wish to clear yourselves of the charge of insurrection ... pay the tax. (JW 2.403)

The question forces Jesus who has announced the 'empire' ( $\beta \alpha \sigma i \lambda \varepsilon i ́ \alpha)$ of God publicly to acknowledge or disavow Rome's sovereignty. ${ }^{14}$

- The narrative uses Jesus' thoughts to label their motivation as 'hypocrisy' (Mk 12:15). The questioners' question is not genuine because as elite allies or retainers dependent on Roman good will and patronage they have clearly answered 'yes' in favour of cooperation and the imperial status quo (Saldarini 2001:1-75, 144-157). Using the verb $\pi \varepsilon 1 \rho \alpha ́ \zeta \omega$ [test], Jesus aligns them with the devil who similarly 'tested' Jesus (Mk 1:13). Jesus requests a denarius (Mk 12:15b), a coin not much used in pre-70 Judea. The denarius (Mk 12:15b-16) with its imperial image and legend or inscription identifying the lineage and status of the depicted emperor (Johnson n.d.; Price 1984) is a visual aid, a handheld billboard of Roman power, sovereignty and presence.

- Jesus' questions about 'whose likeness and inscription' could be read variously as protectively ambiguous, disingenuous, disrespectful, or sarcastic (Mk 12:16). In a society in which imperial likenesses were commonplace on coins and statues (Huskinson 2000), the answers are obvious. But therein lies the point. The questions refuse recognition of Roman sovereignty and presence as 'natural'. The questions destabilise the status quo by troubling its normalcy.

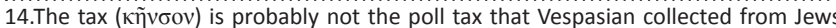
as a conquered people after Jerusalem's fall in 70 to maintain the temple of the victorious Jupiter Capitolinus in Rome (Josephus JW 7.218; Dio Cassius 65.72 ; (ctorious Jupiter Capitolinus in Rome (Josephus JW 7.218; Dio Cassius 65.7.2; Suetonius Domitian 12.2, Mt 17.24-27, Carter 2001). Matthew, Josephus, and Dio Cassius refer to that tax as $\tau \dot{\alpha} \delta i ́ \delta \rho \alpha \chi \mu \alpha$ [didrachma] paid with a $\sigma \tau \alpha \tau \tilde{\eta} \rho$ [starter] Neither term appears here.

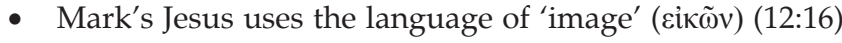
to frame the coin and Roman power. In Israel's scriptural tradition, the noun's dominant meaning denotes humanmade idols that contradict the second commandment (Ex 20:4-6; Dt 5:8-11). The Marcan Jesus' language evokes a tradition of divine condemnation of 'images' spanning Moses (Dt 4:15-20), prophets (Is 40:19-20; Hs 13:2; Dn 2:31-32, 34-35), the Deuteronomistic historian (2 Ki 11:18), the Chronicler (2 Chr 33:7), and wisdom (Wis Sol 13:13, 16; 14:15-21). The term 'image' frames the coin's image and inscription, symbols of Roman power, as blasphemous and idolatrous in violation of the second commandment.

- In this context, Jesus' final statement in Mark 12:17 underscores the antithesis between the blasphemous Caesar and God. Caesar and his efforts (along with provincial elite allies) to foster worship and extend economic and social sovereignty appear contrary to God's purposes and empty before the recognition that all 'things' belong to God (cf. Ps 24:1). The saying in this context reflects a forceful appreciation emerging from the 66-70 war and its Flavian celebrations that Rome's blasphemous power is contrary to God's purposes.

But whilst the scene tips the balance of the final saying from accommodation in the pre-Marcan tradition towards opposition, we must be careful not to overstate this shift in emphasis. The saying continues to hold together 'the things' of Caesar and God; it remains multivalent, ambiguous, covert and complicit. It does not prohibit rendering to Caesar; it permits it and, if the imperative 'render or pay back'

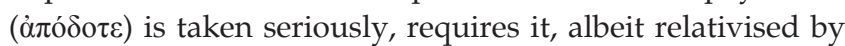
commitment to God. The payment of tax with this coin gives the blasphemous coin back to Caesar, as some have rightly suggested, whilst it denies recognition of the legitimacy of Rome's rule (Herzog 1994:343-50, 2005:182-192). Yet removal of the coin does not thereby remove the blasphemous rule. To the contrary, that rule post-70 CE appears to be stronger than ever and needs negotiating on a daily basis, including tax payment. Non-participation in the Roman world is not an option. Nor is monolithic opposition that refuses any compliance. Jesus-believers continue to live and participate in Rome's world with a fresh realisation of and alliance with its power, idolatry, and blasphemy.

\section{Conclusion}

This article has addressed a disconnect between the plural

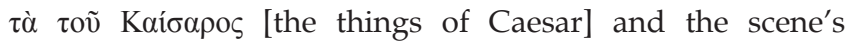
focus on tax paying in terms of a possible developing tradition. Impacted by the 'traumatic' Jewish War and Flavian celebrations, Mark contextualises a saying that sanctioned plural forms of societal participation (paying taxes, commercial activity, imperial cult, joining the army) in a scene marked by cosmic opposition and a presentation of Roman power as blasphemous and idolatrous. The context reorients a saying that previously had primarily accomodationist and permissive functions into a saying that heightens the antithesis between Caesar and God even 
whilst it continues to permit and sanction participation in various spheres of Roman power. The plural the things of Caesar' continues to address various situations despite the scene's singular focus on tax payment. The saying plays off the scene's setting, personnel, and central numismatic image to transcend a narrative focus on taxation alone.

\section{Acknowledgements Competing interests}

The author declares that he has no financial or personal relationship(s) that may have inappropriately influenced him in writing this article.

\section{References}

Aguilar, M., 2005, 'The Archaeology of memory and the issue of colonialism: Mimesis and the controversial tribute to Caesar in Mark 12:13-17', Biblical Theology Bulletin 35, 60-66. http://dx.doi.org/10.1177/01461079050350020401

Aland, K., 1968, 'The telation of Church and State in Early Times: A Reinterpretation', Journal of Theological Studies 19, 115-27. http://dx.doi.org/10.1093/jts/ XIX.1.115

Alexander, J.C., 2004, 'Toward a theory of cultural trauma', in J.C. Alexander, R. Eyerman, B. Giesen, N.J. Smelser \& P. Sztompka (eds.), Cultural trauma and collective identity, pp. 1-30, University of California Press, Berkeley. http://dx.doi collective identity, pp. 1-30, University of California
org/10.1525/california/9780520235946.003.0001

Ariel, D.T., 1982, 'A survey of coin finds in Jerusalem (Until the end of the Byzantine Period)', Liber annuus studii biblici franciscani 32, 273-326.

Bainton, R., 1960, Christian attitudes toward war and peace: An historical survey and critical re-evaluation evaluation, Abingdon, New York.

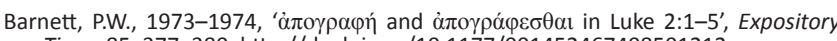
Times 85, 377-380. http://dx.doi.org/10.1177/001452467408501212

Bauckham, R., 1993, 'The economic critique of Rome in Revelation 18', in R. Bauckham (ed.), The climax of prophecy: Studies on the Book of Revelation, pp. 338-383, T \& T Clark, Edinburgh.

Bernett, M., 2007a, Der Kaiserkult in Judäa unter der Herodiern und Römern: Untersuchungen zur politischen und religiösen Geschichte Judäas von $30 \mathrm{v}$. bis 66 n. Chr, Mohr Siebeck, Tübingen.

Bernett, M., 2007b, 'Roman Imperial cult in the Galilee', in J. Zangenberg, H. Attridge \& D. Martin (eds.), Religion, Ethnicity, and Identity in Ancient Galilee: A Region in Transition, pp. 337-356, Mohr Siebeck, Tübingen.

Bilde, P., 1978, 'The Roman Emperor Gaius (Caligula)'s attempt to erect his statue in the Temple of Jerusalem', Studia Theologica 32, 67-93. http://dx.doi. org/10.1080/00393387808599975

Bruce, F.F., 1984, 'Render to Caesar', in E. Bammel \& C.F.D. Moule (eds.), Jesus and the politics of his day, pp. 249-263, Cambridge University Press, Cambridge. http:// dx.doi.org/10.1017/CBO9780511554834.016

Brunt, P., 1990, 'The Revenues of Rome', in P. Brunt (ed.), Roman Imperial themes, pp. 324-346, Clarendon, Oxford.

Bultmann, R., 1963, The history of the Synoptic tradition, Harper \& Row, New York.

Carter, W., 2001, 'Paying the Tax to Rome as Subversive Praxis: Matthew 17:24-27', in Matthew and Empire: Initial Explorations, pp. 130-144, Trinity, Harrisburg.

Carter, W., 2004, 'Honoring the Emperor and sacrificing wives and slaves: 1 Peter 2:13-3:6', in A-J. Levine (ed.), A feminist companion to the general epistles, pp. 13-43, Sheffield Academic Press, Sheffield.

Carter, W., 2006, The Roman Empire and the New Testament: An essential guide, Abingdon Press, Nashville.

Carter, W., 2008, John and empire: Initial explorations, T \& T Clark, New York.

Carter, W., 2009, 'Accommodating 'Jezebel' and withdrawing John: Negotiating Empire in Revelation then and now', Interpretation 63, 32-47. http:// dx.doi.org/10.1177/002096430906300104

Claus, M., 2001, Kaiser und Gott: Herrscherkult im römischen Reich, K.G. Saur, Leipzig. Davies, W.D. \& Allison, D., 1988-1997, The Gospel according to Matthew 3, T\&T Clark, Edinburgh. (International Critical Commentary series).

Deissmann, A., 1922, Light from the Ancient East: The New Testament illustrated by recently discovered texts of the Graeco-Roman World, 4th edn., Harper and Brothers, New York.

Dunn, J.D.G., 2003, Jesus remembered, Eerdmans, Grand Rapids.

Evans, C., 2006, 'The Beginning of the Good News and the fulfillment of Scripture in the Gospel of Mark', in S. Porter (ed.), Hearing the Old Testament in the New Testament, pp. 83-103, Eerdmans, Grand Rapids.

Feldman, L.H. see Josephus.

Fentress, J. \& Wickham, C., 1992, Social memory, Blackwell, Oxford.
Giblin, C., 1971, 'The Things of God' in the question concerning tribute to Caesar (Lk 20:25; Mk 12:17; Matt 22:21)', Catholic Biblical Quarterly 33, 510-527.

Halbwachs, M., 1992, On collective memory, University of Chicago Press, Chicago.

Hanson, R.S., 1980, Tyrian influence in the Upper Galilee, American Schools of Oriental Research, Cambridge, Cambridge.

Hanson, K.C. \& Oakman, D.E., 1998, Palestine in the time of Jesus: Social structures and social conflicts, Fortress, Minneapolis

Harland, P., 2003, Associations, synagogues, and congregations, Fortress, Minneapolis.

Hart, H.St.J., 1984, 'The coin of "render unto caesar ..." (A Note on Some Aspects of Mark 12:13-17; Matt 22:15-22; Luke 20:20-26)', in E. Bammel \& C.F.D. Moule (eds.), Jesus and the politics of his day, pp. 241-248, Cambridge University Press, Cambridge.

Helgeland, J., 1978, 'Roman Army Religion', in H. Temporini \& W. Haase (eds.), Aufstieg und Niedergang der römischen Welt II.16.2, pp. 1470-1505, De Gruyter, Berlin.

Helgeland, J., 1979, 'Christians and the Roman army from Marcus Aurelius to Constantine', in 'H. Temporini \& W. Haase (eds.), Aufstieg und Niedergang der römischen Welt II.23.1, pp. 724-834, De Gruyter, Berlin.

Helgeland, J., Daly, R. \& Burns, J.P., 1985, Christians and the military: The early years, Fortress, Philadelphia.

Herzog, W., 1994, 'Dissembling, a weapon of the weak: The case of Christ and Caesar in Mark 12:13-17 and Romans 13:1-7', Perspectives in Religious Studies 21, in Mark $339-360$

Herzog, W., 2005, Prophet and teacher: An introduction to the historical Jesus, Westminster John Knox, Louisville.

Horsley, G.H.R., 1981, 'Census returns and registers', in New Documents Illustrating Early Christianity, vol. 1, pp. 79-80, The Ancient History Documentary Research Centre, Macquarrie University.

Horsley, G.H.R., 1983, s.v. 'кท́vбos', in S.R. Llewelyn \& G.H.R. Horsley (eds.), New documents illustrating Early Christianity, vol. 3, pp. 70-71, The Ancient History Documentary Research Centre, Macquarrie University.

Horsley, G.H.R., 1987, s.v. 'In memory of Her' in S.R. Llewelyn (ed.), New documents illustrating Early Christianity, vol. 4, pp. 10-13, The Ancient History Documentary Research Centre, Macquarrie University.

Horsley, R., 2008, Jesus in Context: Power, people, \& performance, Fortress, Minneapolis.

Horsley, R., Draper, J. \& Foley, J.M. (eds.), 2006, Performing the Gospel: Orality, memory, and Mark, Fortress, Minneapolis.

Huskinson, J. (ed.), 2000, Experiencing Rome: Culture, identity, and power in the Roman Empire, Routledge, London.

Incigneri, B., 2003, The Gospel to the Romans: The setting and rhetoric of Mark's Gospel, Brill, Leiden.

Johnson, E.S., n.d., 'Mark 12:13-17: Which Caesar's Coin?', unpublished paper.

Josephus, 1965, Jewish Antiquities Books 18-19, transl. L.H. Feldman, Harvard University Press, Cambridge. (Loeb Classical Library).

Kautsky, J., 1982, The politics of aristocratic Empires, University of North Carolina, Chapel Hill.

Kelber, W., 1983, The oral and written Gospel, Fortress, Philadelphia.

Kennard, J.S., 1950, Render to God: A study of the tribute passage, Oxford University Press, New York.

Kirk, A. \& Thatcher, T., 2005, Memory, tradition, and text: Uses of the past in Early Christianity, Society of Biblical Literature, Atlanta. (Semeia Studies, 25).

Kraybill, J.N., 1996, Imperial cult and commerce in John's Apocalypse, Sheffield University Press, Sheffield. (Journal for the Study of the New Testament Supplement Series, 132).

Lenski, G., 1984, Power and Privilege: A theory of social stratification, McGraw-Hill, New York.

Llewelyn, S.R., 1992a, "'And everyone went to his own town to register", Luke 2.3', in S.R. Llewelyn (ed.), New documents illustrating Early Christianity, vol. 6, pp. 112-119, The Ancient History Documentary Research Centre, Macquarrie University.

Llewelyn, S. R.,1992b, 'The provincial census and the birth of Jesus', in S.R. Llewelyn (ed.), New documents illustrating Early Christianity, vol. 6, pp. 119-132, The Ancient History Documentary Research Centre, Macquarrie University.

Llewelyn, S. R., 1997a, 'Flight from Personal Obligations to the State', in S.R. Llewelyn (ed.), New Documents illustrating Early Christianity, vol. 8, pp. 97-105, Eerdmans, Grand Rapids.

Llewelyn, S.R., 1997b, 'Taxes on donkeys: An illustration of indirect taxation at work in Roman Egypt', in S.R. Llewelyn (ed.), New documents illustrating Early Christianity, vol. 8, pp. 77-96, Eerdmans, Grand Rapids.

McLaren, J., 2005, 'Jews and the Imperial Cult: From Augustus to Domitian', Journal for the Study of the New Testament 27, 257-278. http://dx.doi. org/10.1177/0142064X05052506

Meier, J.P., 2001, A marginal Jew: Rethinking the Historical Jesus, vol. 3, Companions and competitors, Doubleday, New York.

Millar, F., 1993, The Roman Near East 31 BC-AD 337, Harvard University, Cambridge.

Milligan, G., 1927, Selections from the Greek Papyri, Cambridge University Press, Cambridge.

Pilgrim, W., 1999, Uneasy neighbors: Church and state in the New Testament, Fortress, Minneapolis. 
Price, S., 1984, 'Gods and Emperors: The Greek language of the Roman Imperial Cult', Journal of Hellenic Studies 104, 79-95. http://dx.doi.org/10.2307/630281

Rist, M., 1936, 'Caesar or God (Mark 12:13-17)? A Study in Formgeschichte', Journal of Religion 16, 317-331. http://dx.doi.org/10.1086/481843

Saldarini, A. J., 2001, Pharisees, scribes, and sadducees in Palestinian society: A sociological approach, Eerdmans, Grand Rapids.

Shaw, B., 1988, 'Roman taxation', in M. Grant \& R. Kitzinger (eds.), Civilization of the Ancient Mediterranean: Greece and Rome, vol. 2, pp. 807-827, Charles Scribner's Sons, New York.

Swift, L.J., 1979, 'War and the Christian Conscience I: The Early Years', in H. Temporin \& W. Haase (eds.), Aufstieg und Niedergang der römischen Welt II.23.1, pp. 835868, De Gruyter, Berlin.
Swift, L.J., 1983, The early fathers on war and military Service, Michael Glazier, Wilmington.

Taylor, J., 2006, 'Pontius Pilate and the Imperial Cult in Roman Judaea' New Testament Studies 52(4), 555-582. http://dx.doi.org/10.1017/ S0028688506000300

Udoh, F.E., 2005, To Caesar what is Caesar's: Tribute, taxes, and imperial administration in Early Roman Palestine 63 B.C.E.-70CE, Brown University Press, Providence. (Brown Judaic Studies, 343).

Wallace, S., [1938] 1969, Taxation in Egypt from Augustus to Diocletian, Greenwood New York.

Winn, A., 2008, The purpose of Mark's Gospel: An Early Christian response to Roman Imperial propaganda, Mohr Siebeck, Tübingen. 